\title{
GABDULHAEV BILSUR GABDULHAEVICH AND HIS SCIENTIFIC HERITAGE
}

\author{
Anis Foatovich Galimzhanov, \\ Kazan Federal University, \\ 18 Kremlyovskaya Str., Kazan, 420008, Russian Federation, \\ anis_59@mail.ru.
}

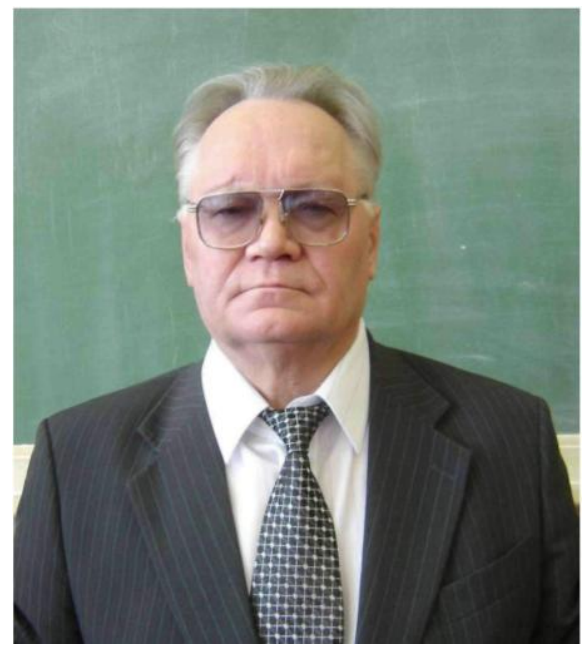

Gabdulhaev Bilsur

Gabdulhaevich (1936-2008) was the founder and head of the Theory of Functions and Approximations Department in KSU (1988-2008), Doctor of Physics and Mathematics (1986), Professor (1987), Corresponding Member of the Academy of Sciences of the Republic of Tatarstan (1992), Honored Scientist of the Republic of Tatarstan (1997), a member of the Board of Governors of the American Biographical Institute, USA (1997).

He published about two hundred research papers, three monographs and several review papers on contemporary problems of functions and approximations theory, functional analysis and integral equations, as well as several textbooks.

His scientific research was devoted to optimal methods for solving operator equations.
Габделхәев Билсур Габделхәй улы (1936-2008) Казан дәүләт университетының функцияләр теориясе hәм якынайтулар кафедрасына нигез сала һәм шул кафедраның мөдире була (19882008). Физика-математика фәннәре докторы (1986), професcop (1987), ТР ФА әГъзакорреспонденты (1992), Татарстан Республикасы атказанган фән эшлеклесе (1987), АКШ Америка институтының идарә советы әгъзасы (1997).

Ике йөзгә якын фәнни хезмәт, өч монография, функцияләр теориясе һәм якынайтулар, функциональ анализ, интеграль тигезләмәләрнең заманча проблемаларына караган мәкаләләр, шулай ук берничә уку-укыту әсбабы авторы.

Фәнни тикшеренүләре оператор тигезләмәләрне оптималь чишү ысулларына багышлана.
Габдулхаев Билсур Габдулхаевич (1936-2008). Основатель и заведующий кафедрой теории функций и приближений КГУ (1988-2008). Доктор физикоматематических наук (1986), профессор (1987), членкорреспондент АН РТ (1992 г.). Заслуженный деятель науки Республики Татарстан (1997). Член Совета управляющих Американского биографического института США (1997).

Опубликовал около двухсот научных работ, три монографии и несколько обзорных работ по современным проблемам теории функций и приближений, функционального анализа и интегральных уравнений, а также несколько учебных пособий.

Научные исследования посвящены оптимальным методам решения операторных уравнений.
Gabdulhaev Bilsur Gabdulhaevich, Doctor of Physics and Mathematics, Professor of Kazan University, was born on the $29^{\text {th }}$ of October in 1936 in Chistoprudnoe village of the Kurgan region. As the family came from the village of Yangulovo, the Baltasinsky district of Tatarstan, they returned to their homeland. He left school in the village of Yangulovo, the Baltasinsky district, and entered 
the Kazan Agricultural Institute in 1955. There, he attended lectures delivered by the prominent Tatar mathematician Shaidukov Gumer Mirsaidovich. The teacher identified his student's talent for mathematics and invited him to Kazan University. At his suggestion, in 1956, B. Gabdulhaev, having successfully passed the exams, became a student of the Mathematics Department at the Physics and Mathematics Faculty of Kazan University. From that time, his fate was inextricably linked with Kazan University.

From his university years, B. Gabdulhaev was actively engaged in scientific research under the guidance of Prof. B. Gagaev (1897-1975), the head of the Mathematical Analysis Department and a prominent scientist. After graduating from the university in 1961, he did a postgraduate course. Five months later, at the suggestion of his scientific supervisor, he began to work as an assistant in the Mathematical Analysis Department and got a position at the Correspondence Department of Graduate School. From that time, for many years, Bilsur Gabdulhaev taught mathematics to university students.

In 1966, he defended his thesis on the subject "Some questions of the theory of approximate methods and their applications to the numerical solution of singular integral equations". The supervisor and reviewers highly appreciated the work, and V. Ivanov, a Corresponding Member of the Academy of Sciences of the USSR, even suggested presenting it as a doctoral dissertation in the same year. However, B. Gabdulhaev was too modest and refused this offer.

In the 1970s, B. Gabdulhaev was an assistant professor at the universities of Sofia and Plovdiv in Bulgaria. He also collaborated with the Bulgarian Academy of Sciences. In Bulgaria, there are his disciples who prepared their candidate and doctoral dissertations under his guidance.

One of the results of B. Gabdulhaev's versatile research work is a functional analysis of the general theory of approximate methods. This theory can be used with respect to broad classes of operator equations, their problem of solving can be posed both correctly and incorrectly. A researcher, aiming to solve similar equations which are widely used in practice, created a special optimal apparatus of polynomial and spline approximations of functions in the spaces of Helder, Nikolsky, and Sobolev. They are used to create optimal quadrature and cubature formulas for calculating optimal regular and singular integrals. The results of these studies were described in numerous articles and three monographs ([Gabdulhaev, Optimalnye approksimatsii], [Gabdulhaev, Konechnomernye approksimatsii], [Gabdulhaev, 1994], [Gabdulhaev, 1995]).

In 1986, B. Gabdulhaev presented his doctoral dissertation at the Institute of Mathematics of the Academy of Sciences of the Ukrainian SSR (Kiev) on "Optimal approximations of solutions to linear problems and direct methods for solving singular integral equations". The scientist published more than 50 articles and a monograph in this area. Prof. S. Mikhlin, an official opponent of the work and a major expert in computational methods and mathematical physics, noted that this dissertation made a huge contribution to mathematics.

B. Gabdulhaev understood the importance of computer technology in scientific research at its initial stage, and the first computer class at the Faculty of Mechanics and Mathematics was opened at the expense of an economic contract headed by him. Due to his efforts, the Department of the Theory of Functions and Approximations was created in 1988. One of the priority tasks at the new department was to implement computer technology in scientific and pedagogical activities of the faculty. B. Gabdulhaev was the head of this department till the end of his days.

The scientist paid great attention to the education of the young generation, especially the involvement of young people in scientific research. In 1974, the work of his scientific school began with scientific seminars "Theory of approximation and its applications". In addition to students from Kazan, this event, scheduled at four every Thursday, was attended by his students from the cities of the Soviet Union such as Novosibirsk (Russia), Chisinau (Moldova), Dushambe (Tajikistan), Kiev, Kharkov, Odessa (Ukraine), Minsk (Belarus). B. Gabdulhaev also supervised the work of foreign postgraduates. In total, he prepared forty candidates of science and four doctors of science.

For ten years (1998-2008), the scientist was a member of the editorial board of the international journal "Izvestiya Vuzov. Maths" (Russian Mathematics), and in 1970-1980, he was a deputy editor-in-chief of this journal. B. Gabdulhaev's students noted his thoroughness in writing research papers and in evaluating the results found. His favorite expression was "Even if I don't know exactly how to work, I know exactly how not to work."

In 1992, B. Gabdulkhaev was elected a Corresponding Member of Tatarstan Academy of Sciences and acted as the chairman of the Scientific Council for Mathematics. For the past ten years he 
was the chairman of the Scientific Council for Mathematics and Mechanics.

In 1996, by the decision of independent experts from various countries, B. Gabdulhaev was recognized as a person who had achieved outstanding success in the field of higher mathematics, which was supported by the American Biographical Institute (ABI), he was recommended to be included in the "International Directory of 500 Influential Individuals" in the "Science" section and awarded the US ABI gold medal.

The scientist had many achievements and discoveries in the field of science. Today, his students are all over the world. The motto of my mentor, to which he was faithful all his life, was "Do good and hide it in the water". The works of B. Gabdulhaev who imparted quality knowledge to thousands of students have blazed the path of science for many people, for many years in the field of mathematics. Being tough outwardly, he was kind at heart, more demanding of himself than of others, hardworking until the end of his life, my mentor was a real Baltasi man...

\section{References}

Gabdulhaev, B. G. (1980). Optimalnye approksimatsii reshenii lineynykh zadach [Optimal Approximations of Solutions to Linear Problems]. 231 p. Kazan, izd-vo Kazan univ-ta. (In Russian)

Gabdulhaev, B. G. (1980). Konechnomernye approksimatsii singulyarnykh integralov pryamye metody resheniia osobykh integralnykh $\mathrm{i}$ integrodifferentsialnykh uravnenii [Finite-dimensional Approximations of Singular Integrals Direct Methods for Solving Singular Integral and Integro-differential Equations]. Vol. 18. 57 p. Itogi nauki I tekhniki. Matem. analiz. Moscow, izd-vo AN SSSR. (In Russian)

Gabdulhaev, B. G. (1994). Priamye metody resheniia singuliarnykh integralnykh uravnenii pervogo roda. Chislennyi analiz [Direct Methods for Solving Singular Integral Equations of the First Kind. Numerical Analysis]. 288 p. Kazan, izd-vo Kazan univ-ta. (In Russian)

Gabdulhaev, B. G. (1995). Chislennyi analiz singulyarnykh integralnykh uravneniy. Izbrannye glavy. [Numerical Analysis of Singular Integral Equations. Selected Chapters]. 230 p. Kazan, izd-vo Kazan univ-ta. (In Russian)

\title{
ГАБДЕЛХӘЕВ БИЛСУР ГАБДЕЛХӘЙ УЛЫ ҺӘМ АНЫН ФӘННИ МИРАСЫ
}

\author{
Әнис Фоат улы Галимқанов, \\ Казан федераль университеты, \\ Россия, 420008, Казан ш., Кремль ур., 18 нче йорт, \\ anis_59@mail.ru.
}

Физика-математика фәннәре докторы Казан университеты профессоры Габделхәев Билсур Габделхәй улы 1936 нчы елның 29 нчы октябрендә Курган өлкәсенең Чистопрудное авылында туа. Гаиләләренең төп чыгышы Татарстанның Балтач районы Яңгул авылыннан булганга, алар туган якларына әйләнеп кайталар. Ул урта мәктәпне Балтач районының Яңгул авылында тәмамлый һәм 1955 нче елда Казан авыл хужалыгы институтына укырга керә. Ул анда күренекле татар математигы Шайдуков Гомәр Мирсәет улының лекцияләрен тыңлый. Укытучысы шәкертенең математика фәненә сәләтен күреп ала һәм аны Казан университетына чакыра. Аның тәкъдиме белән, Габделхәев Б. Г. киләсе 1956 нчы елда ук имтиханнарны бик яхшы билгесенә генә тапшырып, Казан университеты физика-математика факультетының «Математика» бүлеге студенты була. Шул вакыттан башлап, аның язмышы Казан университеты белән аерылгысыз бәйләнгән.

Габделхәев Б. Г. студент чагыннан ук математик анализ кафедрасы мөдире, профессор, атаклы галим Б. М. Гагаев (1897-1975) житәкчелегендә фән белән интенсив шөгыльләнә башлый, ә 1961 нче елда университетны тәмамлап, аспирантурага керә. Биш айдан соң ул, фәнни житәкчесе тәкъдиме белән, математик анализ кафедрасы ассистенты вазифасында эшли башлый һәм аспирантурада читтән торып укуга күчә. Шул вакыттан озак еллар дәвамында Билсур Габделхәй улы студентларны математика фәненең нечкәлекләренә өйрәтә.

1966 нчы елда ул «Якынча ысуллар теориясенең кайбер мәсьәләләре һәм аларны сингуляр интеграль тигезләмәләрдә куллану» темасына кандидатлык диссертациясен яклый. Хезмәткә фәнни житәкче һәм бәяләүчеләр юга- 
ры бәя бирәләр, ә СССР ФА нең әгъзакорреспонденты В. К. Иванов хәтта аны шул ук елда докторлык диссертациясе итеп якларга тәкъдим итә. Ләкин артык тыйнак һәм үз-үзенә таләпчән Б.Г. Габделхәев бу тәкъдимнән баш тарта.

1970 нче елларда Б. Г. Габделхәев Болгариянең София һәм Пловдив университетлары доценты. Ул шулай ук Болгария Фәннәр академиясе белән хезмәттәшлек итә. Болгариядә аның житәкчелегендә кандидатлык hәм докторлык диссертацияләре яклаган шәкертләре бар.

Б. Г. Габделхәевнең күпкырлы фәнни эшчәнлегендәге төп нәтижәләренең берсе функциональ анализ якынча ысулларының гомуми теориясе. Бу теория корректлы һәм корректлы булмаган чишелешле оператор тигезләмәләренең гаять зур төркеменә карата кулланыла ала. Галим, практикада киң кулланыла торган мондый тигезләмәләрне чишү өчен, Гельдер, Никольский, Соболев киңлекләрендә функцияләрне күпбуыннар һәм сплайннар белән якынайтуның махсус оптималь аппаратын эшли. Алар ярдәмендә, оптималь регуляр һәм сингуляр интегралларны исәпләу өчен, оптималь квадратур һәм кубатур формулалар төзелә. Бу эзләнүләрнең нәтижәләре күпсанлы мәкаләләрдә һәм өч монографиядә чагылыш таба ([Габдулхаев, Оптимальные аппроксимации], [Габдулхаев, Конечномерные аппроксимации], [Габдулхаев, 1994], [Габдулхаев, 1995]).

1986 нчы елда УССР ФА нең Математика институтында (Киев) Габделхәев Б. Г. «Сызыкча мәсьәләләр чишелешләренең оптималь аппроксимациясе һәм сингуляр интеграль тигезләмәләр чишүнең туры ысуллары» темасына докторлык диссертациясен яклый. Галимнең әлеге юнәлештә 50 дән артык мәкалә һәм монографиясе басылган. Хезмәтнең рәсми оппоненты, исәпләү ысуллары һәм математик физика буенча күренекле белгеч, профессор Михлин С. Г. бу диссертациянең математика фәненә күренекле өлеш кертүен билгеләп үтә.

Габделхәев Б. Г. компьютер технологияләренең фәнни тикшеренүләрдә мөһимлеген башлангыч чорда ук аңлый һәм ул үзе житәкләгән хужалык килешүләре акчасына механика-математика факультетында беренче компьютер классын ачыла. Аның тырышлыгы белән, 1988 нче елда функцияләр теориясе һәм якынайтулар кафедрасы төзелә. Яңа кафедрада иң мөһим мәсьәләләрнең берсе булып, факуль- теттагы фәнни эшләр һәм уку-укыту процессларына компьютер технологияләрен кертү тора. Габделхәев Б. Г. гомеренең азагына кадәр бу кафедраның мөдире була.

Галим яшь буынны тәрбияләүгә, аеруча фәнгә яшьләрне тартуга зур игътибар бирә. Аның фәнни мәктәбенең чишмә башы 1974 нче елдан башлап эшләгән «Аппроксимация теориясе һәм аның кулланышлары» дигән фәнни семинарлардан башлана. hәр атна саен пәнжешәмбе көнне сәгать дүрткә билгеләнгән бу чарага галимнең Казандагы шәкертләреннән тыш, ә ул вакыттагы Советлар Союзының Новосибирск (Россия), Кишинев (Молдавия), Дүшәмбе (Тажикстан), Киев, Харьков, Одесса (Украина), Минск (Белоруссия) шәһәрләрендә яшәүче шәкертләре дә килә торган булалар. Габделхәев Б. Г. чит илләрдән килгән аспирантлар белән дә житәкчелек итә. Ул барлыгы кырык фәннәр кандидаты һәм дүрт фәннәр докторы әзерли.

Галим ун ел дәвамында (1998-2008) - Халыкара «Югары уку йортлары хәбәрләре. Математика» (Russian Mathematics) журналының редколлегия әгъзасы, ә 1970-1980 елларда бу журналның баш редактор урынбасары булып эшли. Б. Г. Габделхәевнең укучылары аның фәнни эшләрне язуга, тапкан нәтижәләрне бәяләүгә таләбе бик югары булуын искә алалар. Аның яраткан әйтеме: «Мин ничек эшләргә кирәген анык әйтә алмасам да, ничек эшләмәскә кирәк икәнен төгәл беләм».

1992 нче елда Б. Г. Габделхәев Татарстан Фәннәр Академиясенең әгъза-корреспонденты булып сайлана һәм математика буенча Фәнни совет рәисе вазифаларын, ә соңгы ун елда - математика һәм механика буенча Фәнни совет рәисе вазифаларын башкара.

1996 нчы елда төрле илләрнең бәйсез экспертлары карары нигезендә Габделхәев Б. Г. Америка Биографик Институты (АБИ) тарафыннан югары математика өлкәсендә күренекле уңышларга ирешкән кеше дип табыла һәм «Фән» бүлеге буенча «500 күренекле кеше Халыкара белешмәсе»нә кертелергә тәкъдим ителә, АКШ АБИ ның алтын медале белән бүләкләнә.

Галимнең фән өлкәсендә ирешкән уңышлары, ачышлары гаять күп. Аның шәкертләре бүгенге көндә бөтен дөньяга таралган. Остазымның ул кешегә әйтмәгән, ләкин гомере буе тугры калган девизы - «Яхшылык эшлә дә, суга сал». Меңнәрчә студентларга төпле белем биргән, күпме кешене фән юлына 
алып чыккан Б.Г Габделхәевнең математика өлкәсендә башкарган эшләре әле озак еллар галимнәргә маяк булып торыр. Тыштан кырыс, ләкин йомшак күңелле, башкаларга караганда үзенә күбрәк таләпчән, гомер ахырына кадәр жигелеп эшләгән чын Балтач ире иде остазым...

\section{Әдәбият}

Габдулхаев Б. Г. Оптимальные аппроксимации решений линейных задач. Казань: Изд-во Казанского университета, 1980, $231 \mathrm{c.}$
Габдулхаев Б. Г. Конечномерные аппроксимации сингулярных интегралов прямые методы решения особых интегральных и интегродифференциальных уравнений // Итоги науки и техники. Матем. анализ. М.: Изд-во АН СССР, 1980. Вып. 18.57 с.

Габдулхаев Б. Г. Прямые методы решения сингулярных интегральных уравнений первого рода. Численный анализ. Казань: Изд-во Казанск. ун-та, 1994. 288 c.

Габдулхаев Б. Г. Численный анализ сингулярных интегральных уравнений. Избранные главы. Казань: Изд-во Казанск. ун-та, 1995. 230 с. 